\title{
CORPORATE SOCIAL RESPONSIBILITY (CSR) JAKO KONCEPCJA PORZĄDKUJĄCA RELACJE MIĘDZY BIZNESEM A SPOŁECZEŃSTWEM
}

\author{
„Nie wystarczy, by biznes czynił to, co do niego należy; \\ musi również czynić dobro. \\ Ale aby czynić dobro, biznes musi najpierw czynić to, \\ co do niego należy i jak należy" \\ Peter F. Drucker \\ „Społeczna odpowiedzialność zaczyna się tam, \\ gdzie kończy się zasięg oddziaływania prawa"
}

Keith Davis ${ }^{2}$

\begin{abstract}
Koncepcja społecznej odpowiedzialności zmienia się, ewoluuje i wciąż jest przedmiotem publicznej debaty. Obecnie CSR to nie tylko idea, ale także podejście do zarządzania. Stopniowo zaczyna być postrzegany, jako element zarządzania organizacją. Tworząc strategie rozwoju w oparciu o założenia CSR, organizacje poszukują synergii pomiędzy ekonomicznymi, społecznymi i środowiskowymi aspektami funkcjonowania. Mimo coraz większej liczby zwolenników koncepcji nadal można spotkać także jej przeciwników. Najcześciej wymienianym przez nich argumentem jest zysk, jako jedyny cel organizacji biznesowej. Warto podkreślić, że założenie to nie jest sprzeczne z filozofią społecznej odpowiedzialności. CSR nie kwestionuje bowiem prawa do zyskowności, ważny jest natomiast sposób, w jaki organizacja ten cel osiaga. W integrowaniu społecznej odpowiedzialności z działalnością organizacji niezwykle ważne jest zrozumienie filozofii społecznej odpowiedzialności, jej zasad i korzyści z nią związanych. Tymczasem w ogólnopolskim badaniu wiedzy o CSR jedynie 3\% dorosłych Polaków potwierdziło, że spotkało się z pojęciem społecznej odpowiedzialności biznesu lub z angielskim odpowiednikiem tego pojęcia. Czym jest i na czym polega odpowiedzialny biznes? Jaki jest stosunek organizacji do kwestii odpowiedzialności społecznej? Jakie argumenty przedstawiają zwolennicy, a jakie przeciwnicy wdrażania CSR w organizacjach? Jak koncepcja społecznej odpowiedzialności rozwija się w Polsce? Jakie działania można podjąć w celu upowszechnienia wiedzy na temat CSR wśród różnych zaangażowanych stron? Celem artykułu jest przybliżenie czytelnikowi zagadnienia społecznej odpowiedzialności oraz próba odpowiedzi na te pytania.
\end{abstract}

Słowa kluczowe: CSR, Corporate Social Responsibility, społeczna odpowiedzialność biznesu, zrównoważony i odpowiedzialny biznes, społeczna odpowiedzialność.

\footnotetext{
${ }^{1}$ Mgr Iwona Ślęzak-Gładzik, Katedra Systemów Zarządzania i Logistyki, Wydział Zarządzania, Politechnika Rzeszowska, e-mail: igladzik@prz.edu.pl, al. Powstańców Warszawy 8, 35-959 Rzeszów, tel. (17) 8651493. ${ }^{2}$ W latach siedemdziesiątych XX wieku KeithDavis sformułował tzw. żelazne prawo odpowiedzialności(Davis's Iron Law of Responsibility), którego głównym założeniem była konieczność ponoszenia przez przedsiębiorców/menedżerów odpowiedzialności za podejmowane decyzje współmiernie do posiadanej przez nich władzy. Więcej informacji np. A. Rudnicka, CSR - doskonalenie relacji spotecznych w firmie, Wolters Kluwer Polska, Warszawa 2012, s. 37-38.
} 


\section{WPROWADZENIE}

Koncepcja społecznej odpowiedzialności biznesu (CSR, CorporateSocialResponsibility) to filozofia działania oparta na zasadzie poszanowania interesów wszystkich podmiotów funkcjonujących w organizacji oraz jej otoczeniu.

W pierwotnym ujęciu wskazywała na obowiązki, jakie przedsiębiorcy mają wobec społeczeństwa. Howard R. Bowen, uznawany za ojca tej koncepcji, zdefiniował społeczną odpowiedzialność przedsiębiorców jako „obowiązek prowadzenia polityki, podejmowania decyzji oraz realizowania działań, które są zbieżne z oczekiwaniami społecznymi”3.

Mimo rozwoju koncepcji okazało się, że wzbudza ona zarówno pozytywne, jak i negatywne reakcje. Wśród oponentów wymienić można Miltona Friedmana, który uważał, że „odpowiedzialność społeczna spoczywa wyłącznie na jednostkach, zaś odpowiedzialność firm ogranicza się do zapewnienia zysku udziałowcom"4. Podkreślał, że wyłącznym celem działania przedsiębiorcy jest maksymalizacja zysków w imię zobowiązań wobec swoich udziałowców ${ }^{5}$.

Ze stanowiskiem Friedmana polemizował między innymi Peter F. Drucker ${ }^{6}$. „Próżne jest dowodzenie amerykańskiego ekonomisty i laureata Nagrody Nobla, Miltona Friedmana [...], że biznes odpowiada jedynie za ekonomię swego działania. Ekonomia działania jest pierwszq odpowiedzialnością biznesu. Biznes nieprzynoszący zysku, przynajmniej równego wartości zainwestowanego weń kapitału, jest społecznie nieodpowiedzialny. Marnuje zasoby społeczne. Ekonomia wykonywania działań jest podstawą, bez niej biznes nie może podjąć żadnej innej odpowiedzialności, nie może być dobrym pracodawca, dobrym obywatelem, dobrym sąsiadem" " - pisał Drucker. Jednocześnie - jak podkreślał - „ekonomia działań nie jest jedyną sferą odpowiedzialności przedsiębiorstwa [...]. Każda organizacja musi przyjąć odpowiedzialność za wpływ, jaki wywiera na swych pracowników, na otoczenie, klientów i każdy podmiot, z jakim ma kontakt. To odpowiedzialność społeczna"».

Obecnie coraz częściej CSR jest postrzegany jako element zarządzania organizacją. Przedsiębiorstwa tworząc strategie rozwoju dobrowolnie uwzględniają $W$ swoich działaniach interesy społeczne, dobro środowiska naturalnego, a także relacje z różnymi grupami interesariuszy ${ }^{9}$.

\footnotetext{
${ }^{3}$ H. Bowen, Social responsibility of the businessman, Harper \& Row, New York 1953,cyt. za: A. Rudnicka, op.cit., s. 39

${ }^{4}$ M. Friedman, The Social Responsibility of Business Is to Increase its Profits, „New York Times Magazine” 13.09.1970, cyt. za: M. Bernatt, Spoteczna odpowiedzialność biznesu. Wymiar konstytucyjny i międzynarodowy, Wydawnictwo Naukowe Wydziału Zarządzania Uniwersytetu Warszawskiego, Warszawa 2009, s. 24.

${ }^{5}$ M. Friedman, Capitalism and Freedom, University of Chicago Press, Chicago 1962, s. 133-134,cyt. za: M. Bernatt, Społecznaodpowiedzialnośćbiznesu. Wymiar konstytucyjny i międzynarodowy, Wydawnictwo Naukowe Wydziału Zarządzania Uniwersytetu Warszawskiego, Warszawa 2009, s. 24

${ }^{6}$ W. Gasparski, Infrastruktura etyczna biznesu, [w:] Biznes, etyka, odpowiedzialność, red. W. Gasparski, Wydawnictwa Profesjonalne PWN, Warszawa2012, s. 218.

${ }^{7}$ P.F. Drucker, Społeczeństwo prokapitalistyczne, WN PWN, Warszawa 1999, s. 86-87,cyt. za: W. Gasparski, op.cit., s. 219.

${ }^{8}$ P.F. Drucker, J.A. Maciariello,Drucker na każdy dzień. 366 refleksji o dobrych praktykach zarzqdzania, Wydawnictwo Eksplanator, Poznań 2011, s.126.

${ }^{9}$ Interesariusze (stakeholders), określani również jako strony zainteresowane, to grupy lub jednostki, które mogą wpływać lub są pod wpływem działania przedsiębiorstwa za pośrednictwem jego produktów, strategii procesów wytwórczych, systemów zarządzania i procedur (B. Rok Odpowiedzialny biznes $w$ nieodpowiedzialnym świecie, Akademia Rozwoju Filantropii w Polsce, Forum Odpowiedzialnego Biznesu, Warszawa 2004, s. 19)
} 
Oprócz najpopularniejszego terminu ,społeczna odpowiedzialność biznesu”, oraz skrótu „CSR” można spotkać się z określeniami typu: „odpowiedzialny biznes”, „odpowiedzialność biznesu”, „społeczna odpowiedzialność przedsiębiorstw”, „przedsiębiorstwo obywatelskie”, „społeczne zaangażowanie biznesu”, „firma zrównoważonego rozwoju". Wielość i różnorodność terminów powoduje, że pojawiają się opinie, iż termin ,społeczna odpowiedzialność biznesu” jest nieudany, mylący i powinno się z niego zrezygnować. Część autorów proponuje zachować akronim „CSR”, który jest popularny i stanowi swoistą markę, proponują natomiast inne jego rozwinięcia, na przykład „odpowiedzialność biznesu wobec interesariuszy” (corporate stakeholde rresponsibility), „strategiczna odpowiedzialność przedsiębiorstwa” (corporate strategic responsibility) lub „odpowiedzialny i zrównoważony biznes” (corporate sustainability and responsibility $)^{10}$.

W niniejszej publikacji używane są zamiennie terminy: społeczna odpowiedzialność, społeczna odpowiedzialność biznesu, odpowiedzialny biznes, społeczna odpowiedzialność przedsiębiorstw, zrównoważony i odpowiedzialny biznes oraz skrót CSR.

\section{CZYM JEST ODPOWIEDZIALNY BIZNES?}

Mimo, że koncepcja CSR przeszła dynamiczny rozwój w ciagu ostatnich kilkudziesięciu lat, w Polsce ciagle rozumiana jest dość wąsko. W wielu firmach utożsamiana jest $\mathrm{z}$ różnymi formami filantropii: sfinansowaniem jakiegoś szczytnego celu lub kampanii społecznej, przyjęciem roli mecenasa kultury czy ze sponsoringiem wydarzenia sportowego. Często towarzyszą temu zapewnienia, że jest to działanie bezinteresowne. Tymczasem, jak twierdził Drucker, dobre intencje nie zawsze mają wiele wspólnego z odpowiedzialnością społeczną. „Przejawem nieodpowiedzialności jest podejmowanie przez organizację zadań - nie mówiąc już o ich realizacji - które będą krępowały jej naturalną zdolność dążenia do własnych celów i wypełniania własnej misji”, ${ }^{11}$ a także: „Podejmowanie działań w ramach społecznej odpowiedzialności przedsiębiorstw, które są ekonomicznie nieuzasadnione, to nie odpowiedzialność, to sentymentalizm" ${ }^{, 2}$.Odpowiedzialny biznes nie polega więc na rozdawaniu pieniędzy, sponsorowaniu wydarzeń kulturalnych czy sportowych. Inicjatywy takie mogą być istotne w realizacji pewnych celów firmy, przynoszą firmie szybkie korzyści wizerunkowe, nie są jednak wystarczające do osiągnięcia konkurencyjności i efektywności ekonomicznej. Istotą tych działań powinna być ich integracja ze strategią biznesową i polityką przedsiębiorstwa. Do pełnego wykorzystania potencjału CSR konieczna jest zatem zmiana myślenia oraz zastąpienie „CSR-owych akcji” na rzecz kompleksowego podejścia do odpowiedzialności społecznej.

Według Bolesława Roka odpowiedzialny biznes to podejście strategiczne i długofalowe, oparte na zasadach dialogu społecznego oraz poszukiwaniu rozwiązań korzystnych dla wszystkich ${ }^{13}$. W publikacji Odpowiedzialny biznes $w$ nieodpowiedzialnym świecie przytacza kilkanaście definicji odpowiedzialnego biznesu:

\footnotetext{
${ }^{10}$ B. Rok, Społeczna odpowiedzialność biznesu, [w:] Biznes, etyka, odpowiedzialność, red. W. Gasparski, Wydawnictwa Profesjonalne PWN, Warszawa 2012, s. 427-428.

${ }^{11}$ P. F. Drucker, J.A. Maciariello, op. cit., s.126.

${ }^{12}$ Ibidem, s. 388.

${ }^{13}$ B. Rok, Odpowiedzialny biznes..., s. 18.
} 
- Osiaganie trwałego zysku przy jednoczesnym rozsądnym kształtowaniu relacji ze wszystkimi interesariuszami.

- Narzędzie zarządzania wykorzystujące proces budowania dialogu z interesariuszami w celu doskonalenia strategii rozwoju firmy.

- Filozofia prowadzenia działalności gospodarczej w oparciu o budowanie trwałych, przejrzystych relacji ze wszystkimi zainteresowanymi stronami, na przykład $\mathrm{z}$ pracownikami, klientami, dostawcami, akcjonariuszami, z konkurencją oraz społecznością lokalną.

- Budowanie strategii przewagi konkurencyjnej na rynku opartej na zapewnieniu trwałej wartości zarówno dla udziałowców, jak i dla innych interesariuszy.

- Dostarczanie usług i produktów w sposób niedegradujący środowiska przyrodniczego i społecznego.

- Uczciwe wypełnianie zobowiązań.

- Budowanie i wdrażanie strategii zaangażowania społecznego, przekraczającego zobowiązania prawne, dla dobra wszystkich obywateli, zgodnie ze społecznie przyjętymi normami etycznymi.

- Wnoszenie wkładu do zrównoważonego rozwoju poprzez współpracę z pracownikami, społecznością lokalną i globalną, aby podnosić jakość życia wszystkich obywateli.

- Poczucie odpowiedzialności za konsumenta, inwestora, społeczeństwo, środowisko przyrodnicze, za sukces gospodarki.

- Stosowanie przejrzystych praktyk biznesowych opartych na szacunku dla pracowników, społeczności i środowiska ${ }^{14}$.

W przełożeniu na język praktyki gospodarczej odpowiedzialny biznes to wychodzenie ponad ogólnie przyjęte normy prawne, działanie ponad minimum i uwzględnianie norm etycznych przy jednoczesnym dbaniu o interesy wszystkich interesariuszy, w tym właścicieli, oraz zapewnianiu sobie stabilnej sytuacji ekonomicznej pozwalającej na rozwój również w długim okresie ${ }^{15}$.

Istotę społecznej odpowiedzialności w nowoczesnym wydaniu najpełniej ujmuje norma ISO 26000,Wytyczne dotyczqce społecznej odpowiedzialnośs $i^{16}$, która definiuje ja jako „odpowiedzialność organizacji za wpływ jej decyzji i działań na społeczeństwo i środowisko zapewniana poprzez przejrzyste i etyczne postępowanie, które:

- przyczynia się do zrównoważonego rozwoju, w tym dobrobytu i zdrowia społeczeństwa;

- uwzględnia oczekiwania interesariuszy;

- jest zgodne $\mathrm{z}$ obowiązującym prawem i spójne $\mathrm{z}$ międzynarodowymi normami postępowania;

- jest zintegrowane z działaniami organizacji i praktykowane w jej relacjach"17.

\footnotetext{
${ }^{14}$ Ibidem, s. $18-19$

${ }^{15}$ A. Rudnicka, op.cit., s. 43.

${ }^{16}$ Norma ISO 26000 została opublikowana w listopadzie 2010 r. przez Międzynarodową Organizację Standaryzacyjną (ISO,International Standarization Organization). Inauguracja polskiej wersji ISO 26000 odbyła się 26 listopada 2012 r. w Ministerstwie Gospodarki.

${ }^{17}$ PN-ISO 26000:2012, s.16.
} 
Kluczowe obszary odpowiedzialności społecznej według wspomnianej normy to: ład organizacyjny; prawa człowieka; praktyki z zakresu pracy; środowisko; uczciwe praktyki operacyjne; kwestie konsumenckie oraz zaangażowanie społeczne i rozwój społeczności lokalnej ${ }^{18}$. Celem ISO 26000 jest zachęcenie organizacji do wyjścia poza nałożone prawem zobowiązania przy jednoczesnym zrozumieniu, że respektowanie prawa jest podstawowym obowiązkiem każdej organizacji i niezbędną częścią jej społecznej odpowiedzialności. Warto również podkreślić, że jest adresowana do różnych organizacji: zarówno biznesowych, jak i dla organów administracji rządowej czy organizacji nonprofit. Nie jest natomiast normą systemu zarządzania, nie jest przeznaczona do celów certyfikacji ani do stosowania w ramach regulacji lub umów ${ }^{19}$.

\section{POSTAWY ORGANIZACJI WOBEC ODPOWIEDZIALNOŚCI SPOŁECZNEJ}

Jak zauważa Rok dyskusje wokół społecznej odpowiedzialności biznesu są formą odpowiadania na jeden z najważniejszych dylematów zarówno w teorii zarządzania, jak i w etyce biznesu: „Czy jedyną rolą biznesu jest efektywne angażowanie zasobów do maksymalizacji zysków, nie naruszając przy tym przepisów prawa, czy też rolą biznesu w dzisiejszych czasach jest poszukiwanie rozwiązań, które są korzystne dla wszystkich interesariuszy?"20.

Podejście przyjęte przez organizację w kwestii odpowiedzialności społecznej może odzwierciedlać mniejsze lub większe zaangażowanie. Ricky W. Griffin wymienia cztery typy postaw organizacji wobec społecznych zobowiązań: od postawy obstrukcjonistycznej, poprzez postawę obronną i postawę dostosowawczą, po postawę aktywną ${ }^{21}$ :

- postawa obstrukcjonistyczna- organizacje, które przyjmują taką postawę, robią możliwie jak najmniej dla rozwiązywania problemów społecznych czy ekologicznych. Kiedy przekraczają granice (prawne lub etyczne) dzielące działania akceptowane od nieakceptowanych wypierają się odpowiedzialności lub ukrywają wszelkie nieprawidłowości,

- postawa obronna - organizacja czyni wszystko, czego wymaga od niej prawo, ale nic ponad to. Podstawowym argumentem tych organizacji jest to, że ich praca polega na tworzeniu zysku. Firmy przyjmujące taką postawę raczej nie tuszują nieprawidłowości oraz są skłonne przyznać się do błędów i podjąć działania naprawcze,

- postawa dostosowawcza - organizacja wypełnia swoje obowiązki prawne i etyczne, a także w wybranych przypadkach jest skłonna zrobić więcej niż wynika to $\mathrm{z}$ tych obowiązków,

- postawa aktywna - najwyższy poziom odpowiedzialności społecznej, organizacje uznają się za odpowiedzialnych członków społeczeństwa i aktywnie poszukują możliwości przyczynienia się do dobra społecznego.

\footnotetext{
${ }^{18}$ Ibidem,s. 31-32.

${ }^{19}$ Ibidem,s. 13.

${ }^{20}$ B. Rok, Społeczna odpowiedzialność..., s. 424.

${ }^{21}$ R.W. Griffin, Podstawy zarzadzania organizacjami, Wydawnictwo Naukowe PWN, Warszawa 2004, s. 122125.
} 
Agata Rudnicka przytacza inny, spotykany w literaturze przedmiotu podział rodzajów nastawienia organizacji do zarządzania sferą pozaekonomiczną:

- polityka ad-hoc, która bierze pod uwagę kwestie społeczne mogące stanowić ryzyko dla organizacji,

- standardowa polityka społeczna - w polu zainteresowania przedsiębiorstwa pozostają tylko kwestie społeczne, którymi obowiązkowo musi się zająć,

- zaplanowana polityka społecznej odpowiedzialności - menedżerowie uwzględniają kwestie społeczne, które mogą wpływać na działalność i wyniki podmiotu gospodarczego,

- polityka odpowiedzialności społecznej poddawana przeglądowi - kwestie związane $\mathrm{z}$ zarządzaniem relacjami $\mathrm{z}$ interesariuszami są włączane $\mathrm{w}$ proces budowania strategii ${ }^{22}$.

Najbardziej pożądany jest poziom świadomego przyjęcia przez organizację odpowiedzialności za skutki podejmowanych decyzji w każdym z obszarów jej aktywności. Jak zauważa Rudnicka: „przedsiębiorstwa, w których społeczna odpowiedzialność zostaje wdrożona do strategii, wykazują wysoki poziom interakcji z interesariuszami. Włączają się w różnego rodzaju projekty społeczne i środowiskowe, przeznaczając posiadane zasoby finansowe, dzieląc się wiedzą i umiejętnościami oraz angażując swoich pracowników. Skala podejmowanych przedsięwzięć i ich różnorodność wskazują na kompleksowość podejścia do odpowiedzialnego zarządzania" ${ }^{, 2}$.

\section{ARGUMENTY ZA SPOŁECZNĄ ODPOWIEDZIALNOŚCIĄ I PRZECIW NIEJ}

Mimo że panuje dość duża zgodność poglądów co do potrzeby włączania elementów społecznej odpowiedzialności do systemu zarządzania, to nadal podzielone są zdania co do zasadności koncepcji jako całości.

Wśród argumentów za wprowadzaniem i rozwijaniem odpowiedzialności społecznej można dostrzec zarówno te dotyczące osiągania celów pozaekonomicznych, jak i te ściśle związane z ciągłością operacji gospodarczych. Argumenty zwolenników CSR są następujące ${ }^{24}$

- Przedsiębiorstwa funkcjonują w społeczeństwie, w którym obowiązują określone normy zachowań, dlatego też powinny brać odpowiedzialność za swoje decyzje i działania, by nie łamać powszechnie obowiązujących zasad.

- Podmioty gospodarcze wywierają negatywny wpływ na otoczenie, w którym funkcjonują (zanieczyszczanie atmosfery i wód, wyczerpywanie zasobów), powinny zatem odgrywać ważną rolę $\mathrm{w}$ rozwiązywaniu problemów $\mathrm{z}$ tym związanych oraz brać pod uwagę wszystkie podmioty narażone na ten wpływ.

- Przedsiębiorstwa często dysponują zasobami (np. nadwyżkami dochodów, wyrobów), które mogłyby służyć rozwiązywaniu problemów społecznych.

- Synergia działań międzysektorowych (biznes, organizacje pozarządowe, administracja publiczna) daje wymierne korzyści beneficjentom działań.

\footnotetext{
${ }^{22}$ A. Rudnicka, op.cit., s.75.

${ }^{23}$ Ibidem, s. 76.

${ }^{24}$ R.W. Griffin, op. cit., s.120-121, A. Rudnicka, op. cit., s. 49-53.
} 
- Działania CSR, które są zaplanowane i zintegrowane z celami organizacji (będące elementem systemu zarządzania), mogą przynieść wymierne korzyści zarówno firmie, jak i jej interesariuszom.

- Dzięki zachowaniom społecznie odpowiedzialnym buduje się zaufanie społeczeństwa do organizacji biznesowych.

Mimo coraz większej liczby zwolenników filozofii społecznej odpowiedzialności i mocnych argumentów na rzecz stosowania jej zasad, nadal można spotkać oponentów tej koncepcji. Najczęściej wymieniane argumenty przeciw społecznej odpowiedzialności to ${ }^{25}$ :

- Przedsiębiorstwo jest jak maszyna, której zadaniem jest osiaganie wytyczonych wcześniej celów. Ludzie w organizacji nie powinni kierować się osobistymi wartościami moralnymi, lecz realizować cele służące organizacji.

- Społeczna odpowiedzialność to narzędzie służące jedynie poprawie wizerunku.

- Przedsiębiorstwa nie zostały powołane do rozwiązywania problemów społecznych.

- CSR jest postrzegany jako dodatkowy koszt i obciążenie dla przedsiębiorstw.

- Ingerencja $\mathrm{w}$ sferę niezwiązaną bezpośrednio $\mathrm{z}$ funkcjonowaniem przedsiębiorstw może rodzić dodatkowe dylematy etyczne bądź możliwość konfliktu interesów.

Zdecydowanie najczęściej jednak wśród wymienianych argumentów przeciwnych społecznej odpowiedzialności wskazuje się na zysk jako jedyny cel organizacji biznesowej. Warto jeszcze raz podkreślić, że to założenie nie stoi w sprzeczności z koncepcją odpowiedzialności społecznej. Powołując się na słowa Druckera: „Nie wystarczy, by biznes czynił to, co do niego należy; musi również czynić dobro. Ale aby czynić dobro, biznes musi najpierw czynić to, co do niego należy. Gdy tylko przedsiębiorstwo zaczyna przywiązywać mniejszą wagę do wydajności ekonomicznej, a przyjmuje na siebie coraz większą odpowiedzialność społeczną, której nie jest w stanie poprzeć wynikami gospodarczymi szybko popada w kłopoty"26. Koncepcja CSR nie kwestionuje prawa do zyskowności, ważny jest natomiast sposób, w jaki organizacja ten cel osiaga.

\section{INICJATYWY NA RZECZ CSR W POLSCE}

Pierwszą istotną inicjatywą na rzecz promowania i rozwoju koncepcji społecznej odpowiedzialności w Polsce było powołanie w 1999 r. Centrum Etyki Biznesu (CEBI), wspólnej inicjatywy Wyższej Szkoły Przedsiębiorczości i Zarządzania im. L. Koźmińskiego ${ }^{27}$ oraz Zespołu Etyki Życia Gospodarczego Instytutu Filozofii i Socjologii Polskiej Akademii Nauk. Centrum Etyki Biznesu jest obecnie ośrodkiem badań i studiów na rzecz rozwoju etyki biznesu w Polsce oraz miejscem spotkania liderów biznesu i świata akademickiego, którym zależy na promowaniu etyki życia gospodarczego jako warunku uprawiania skutecznego i społecznie odpowiedzialnego biznesu. Nawiązuje do najlepszych polskich tradycji naukowych i gospodarczych, jednocześnie korzystając z doświadczeń światowych liderów etyki i odpowiedzialności biznesu ${ }^{28}$.

\footnotetext{
${ }^{25}$ R.W. Griffin, op. cit., s.121-122, A. Rudnicka, op. cit., s. 49-53.

${ }^{26}$ P.F. Drucker, J.A. Maciariello, op. cit., s. 388.

${ }^{27}$ Obecnie Akademia Leona Koźmińskiego.

${ }^{28}$ Więcej informacji: http://www.kozminski.edu.pl/pl/katedry/cebi/cebi/ (dostęp: 7.03.2013).
} 
Kolejną ważną inicjatywą było powstanie w 2000 r. Forum Odpowiedzialnego Biznesu (FOB), obecnie największej i najbardziej znanej organizacji pozarządowej kompleksowo zajmującej się koncepcją społecznej odpowiedzialności biznesu. Nie tylko promuje CSR i wspiera jego rozwój, ale także edukuje studentów, prowadzi badania, realizuje projekty z firmami partnerskimi. Ponadto od 2002 r. wydaje publikację Odpowiedzialny biznes w Polsce. Dobre praktyki będącą podsumowaniem zaangażowania firm w Polsce w realizację zasad odpowiedzialnego biznesu oraz przeglądem innych inicjatyw związanym z CSR w danym roku ${ }^{29}$.

W 2007 r. rozpoczęto realizację Rankingu Odpowiedzialnych Firm (ROF).Ranking publikowany jest przez „Dziennik Gazetę Prawną” pod patronatem Forum Odpowiedzialnego Biznesu, tworzony przez Bolesława Roka z Centrum Etyki Biznesu Akademii Leona Koźmińskiego, a weryfikowany przez firmę PwC. Umożliwia porównanie wyników w poszczególnych obszarach CSR pomiędzy firmami, a także jest cennym instrumentem ułatwiającym uporządkowanie i rozwój strategii odpowiedzialności biznesu. Od 2007 r. łącznie wzięło w nim udział niemal 150 największych spółek działających na polskim rynku ${ }^{30}$.

W 2009 r. odnotowano kolejne ważne dla rozwoju CSR w Polsce wydarzenie: na Warszawskiej Giełdzie Papierów Wartościowych uruchomiono pierwszy w Europie Środkowo-Wschodniej indeks firm odpowiedzialnych społecznie - Respect Index.Projekt Respect Index ma na celu wyłonienie spółek zarządzanych w sposób odpowiedzialny i zrównoważony. Ponadto mocno akcentuje atrakcyjność inwestycyjną spółek, która charakteryzują między innymi jakość raportowania, poziom relacji inwestorskich czy ład informacyjny. Dzięki uwzględnieniu wśród kryteriów kwalifikacyjnych parametru płynności Respect Indeks, podobnie jak inne indeksy giełdowe, stanowi realną referencję dla profesjonalnych inwestorów ${ }^{31}$.

Następną wartą wspomnienia inicjatywą była konferencja „Wspólna odpowiedzialność - jak zwiększyć obecność i skuteczność CSR w UE” zorganizowana przez Forum Odpowiedzialnego Biznesu i Ministerstwo Gospodarki 5 września 2011 r. Była to pierwsza tak duża konferencja na temat roli i znaczenia CSR w całej Europie, a Polska była pierwszym krajem, który w trakcie swojego Przewodnictwa w Radzie Unii Europejskiej tak wiele uwagi poświęcił kwestii społecznej odpowiedzialności biznesu ${ }^{32}$.

Wśród ostatnich istotnych dla rozwoju CSR wydarzeń można wymienić konferencję inaugurującą polską wersję normy ISO 26000 „Wytyczne w sprawie odpowiedzialności społecznej”, która odbyła się 26 listopada 2012 r. w Ministerstwie Gospodarki.

Zaangażowanie w działania na rzecz odpowiedzialnego biznesu widać także na poziomie rządowym. W maju 2009 r. zarządzeniem Prezesa Rady Ministrów powstał międzyresortowy Zespół ds. Społecznej Odpowiedzialności Przedsiębiorstw. Jego zadaniem jest przygotowywanie dla administracji rządowej rekomendacji dotyczących promocji i wprowadzania w życie zasad społecznej odpowiedzialności, w tym:

\footnotetext{
${ }^{29}$ Więcej informacji: http://odpowiedzialnybiznes.pl//pl/o-nas/o-forum-odpowiedzialnego-biznesu/historia/oorganizacji.html (dostęp: 7.03.2013).

${ }^{30}$ Więcej informacji: http://odpowiedzialnybiznes.pl/pl/o-nas/nasze-dzialania/aktualne-projekty/rankingodpowiedzialnych-firm.html (dostęp:7.03.2013).

${ }^{31}$ Więcej informacji http://www.odpowiedzialni.gpw.pl/opis_projektu (dostęp:7.03.2013).

${ }^{32} \mathrm{http}: / /$ odpowiedzialnybiznes.pl/pl/praktyka-csr/aktualnosci (dostęp:7.03.2013)
} 
- proponowanie rozwiązań koordynujących działania poszczególnych organów administracji publicznej w zakresie promocji i wprowadzania zasad CSR,

- analiza i wykorzystywanie doświadczeń oraz upowszechnianie dobrych praktyk w obszarze CSR z innych państw,

- tworzenie warunków lepszej komunikacji oraz dialogu pomiędzy administracją, biznesem, partnerami społecznymi oraz organizacjami pozarządowymi $\mathrm{w}$ sprawach dotyczących CSR $^{33}$.

Opracowana przez zespół diagnoza bieżącej sytuacji w zakresie wdrażania założeń koncepcji CSR w Polsce wskazuje mocne strony, a także wyzwania wymagające zwiększonego zaangażowania (tab. 1).

Wdrażanie standardów CSR wpisuje się w strategiczne dokumenty dotyczące rozwoju gospodarczego Polski, między innymi w założenia Strategii Rozwoju Kraju ${ }^{34}$, w Narodowe Strategiczne Ramy Odniesienia ${ }^{35}$ oraz Strategię Europa $2020^{36}$.

Mówiąc o rozwoju koncepcji CSR, nie można pominąć roli organizacji pozarządowych, powoływanych $w$ celu promowania oraz wspierania idei zrównoważonego rozwoju oraz odpowiedzialnego biznesu, takich jak Forum Odpowiedzialnego Biznesu ${ }^{37}$, Instytut Odpowiedzialnego Biznesu ${ }^{38}$, CSR Impact ${ }^{39}$, Centrum $\mathrm{CSR}^{40}$.

Należy również dodać, że na dynamikę rozwoju CSR istotnie wpływają inicjatywy realizowane na szczeblu międzynarodowym ${ }^{41}$, czyli przez Organizację Narodów Zjednoczonych (ONZ), Organizację Współpracy Gospodarczej i Rozwoju (OECD) czy Unię Europejską, wskazujące na obszary wymagające zaangażowania w celu dostosowania modelu społeczno-gospodarczego do globalnych wyzwań zrównoważonego rozwoju ${ }^{42}$.

\footnotetext{
${ }^{33} \mathrm{http}$ ://www.mg.gov.pl/Wspieranie+przedsiebiorczosci/Zrownowazony+rozwoj/Spoleczna+Odpowiedzialnosc+ Przedsiebiorstw+CSR/Zespol+CSR (dostęp: 7.03.2013).

${ }^{34}$ Priorytety strategiczne: 1. wzrost konkurencyjności i innowacyjności gospodarki; 2. poprawa stanu infrastruktury technicznej i społecznej; 3. wzrost zatrudnienia i podniesienie jego jakości; 4. budowa zintegrowanej wspólnoty społecznej i jej bezpieczeństwa.

${ }^{35} \mathrm{Cel} \mathrm{2.} \mathrm{Poprawa} \mathrm{jakości} \mathrm{kapitału} \mathrm{ludzkiego} \mathrm{i} \mathrm{zwiększenie} \mathrm{spójności} \mathrm{społecznej} \mathrm{oraz} \mathrm{Cel} \mathrm{3.} \mathrm{Budowa} \mathrm{i}$ modernizacja infrastruktury technicznej i społecznej mającej podstawowe znaczenie dla wzrostu konkurencyjności Polski.

${ }^{36}$ Priorytety: zrównoważony rozwój (Zrównoważony rozwój - wspieranie gospodarki efektywniej korzystającej z zasobów, bardziej przyjaznej środowisku i bardziej konkurencyjnej) oraz rozwój sprzyjający włączeniu społecznemu (Rozwój sprzyjający włączeniu społecznemu - gospodarka charakteryzująca się wysokim poziomem zatrudnienia i zapewniająca spójność gospodarczą, społeczną i terytorialna); źródło: http://ec.europa.eu/eu2020/pdf/1_PL_ACT_part1_v1.pdf.

${ }^{37} \mathrm{http}: / /$ odpowiedzialnybiznes.pl/pl (dostęp:7.03.2013).

${ }^{38}$ www.iob.org.pl (dostep:7.03.2013).

${ }^{39} \mathrm{http}: / /$ www.csri.org.pl (dostęp:7.03.2013).

${ }^{40} \mathrm{http}: / /$ www.centrumcsr.pl (dostęp:7.03.2013).

${ }^{41}$ Więcej na temat międzynarodowych inicjatyw na rzecz CSR np. A. Rudnicka, op. cit., s. 211-224.

${ }^{42}$ http://www.mg.gov.pl/files/upload/13678/Rekomendacje_w_zakresie_wdrazania_zalozen_koncepcji_CSR_w_ Polsce.pdf, s.5 (dostęp:7.03.2013).
} 
Tabela 1. Analiza SWOT, diagnoza rozwoju CSR w Polsce

\begin{tabular}{|c|c|}
\hline MOCNE STRONY (Strenghts) & SŁABE STRONY (Weaknesses) \\
\hline $\begin{array}{l}\text { - konstytucyjne umocowanie dla działań na } \\
\text { rzecz zrównoważonego rozwoju, } \\
\text { - odpowiednio zabezpieczone w systemie } \\
\text { regulacji prawo ochrony środowiska, } \\
\text { - prawo pracy, w tym bezpieczeństwa i } \\
\text { higieny pracy, oraz prawa i obowiązki } \\
\text { obywatelskie, } \\
\text { - silne zaangażowanie partnerów społecznych } \\
\text { w działania na rzecz promowania założeń } \\
\text { koncepcji CSR, } \\
\text { - funkcjonowanie jedynego w Europie } \\
\text { Środkowo-Wschodniej etycznego indeksu } \\
\text { giełdowego RESPECT, } \\
\text { - } \text { silne poczucie dobrowolności koncepcji } \\
\text { prowadzące do angażowania się liderów } \\
\text { biznesowych w inicjowanie współpracy } \\
\text { sektorowej oraz międzysektorowej na rzecz } \\
\text { rozwoju branży, } \\
\text { - przywództwo oraz odpowiedzialność w } \\
\text { zakresie problematyki CSR na szczeblu } \\
\text { administracji rządowej (prace Zespołu do } \\
\text { spraw Społecznej Odpowiedzialności } \\
\text { Przedsiębiorstw). }\end{array}$ & 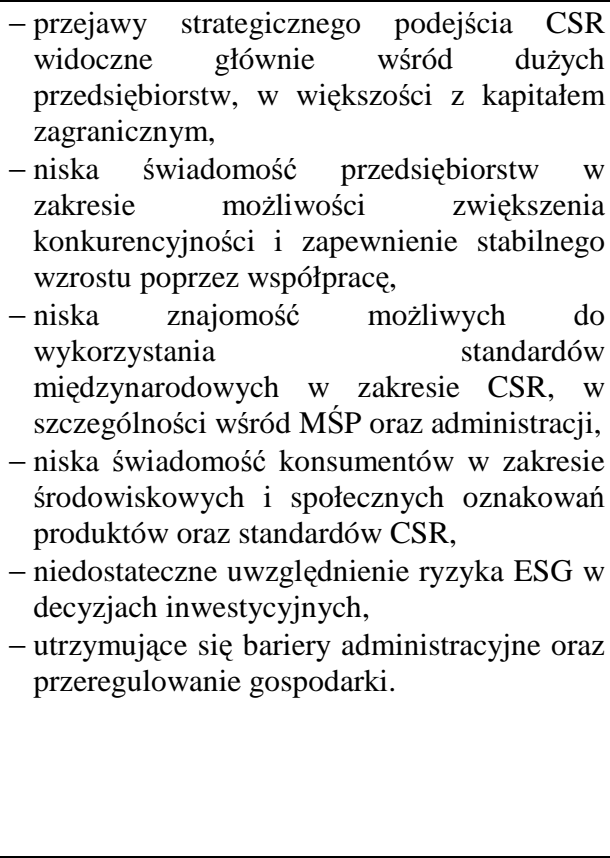 \\
\hline SZANSE $(O p$ & ZAGROŻENIA (Threats) \\
\hline $\begin{array}{l}\text { - wzrost zainteresowania tematyką CSR w } \\
\text { środowisku międzynarodowym, w tym } \\
\text { publikacja normy ISO 26000, } \\
\text { - nowy komunikat Komisji Europejskiej } \\
\text { dotyczący CSR [...], } \\
\text { - stopniowe włączanie założeń CSR do } \\
\text { kierunków rozwoju gospodarczego kraju, } \\
\text { - aktywność Polski na szczeblu } \\
\text { międzynarodowym, w tym ścisła } \\
\text { współpraca przy kształtowaniu unijnej } \\
\text { polityki CSR, również podczas polskiego } \\
\text { przewodnictwa wadzie UE, } \\
\text { - coraz większe zainteresowanie koncepcją } \\
\text { CSR wśród menedżerów biznesu oraz } \\
\text { przedstawicieli mediów. }\end{array}$ & 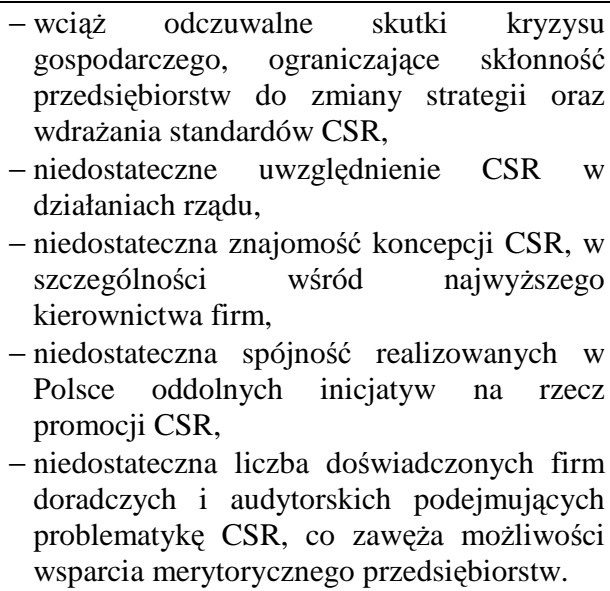 \\
\hline
\end{tabular}

Źródło: Rekomendacje w zakresie wdrażania założeń koncepcji Społecznej Odpowiedzialności Przedsiębiorstw w Polsce ${ }^{43}$,opracowanie Ministerstwa Gospodarki.

\footnotetext{
${ }^{43}$ http://www.mg.gov.pl/files/upload/13678/Rekomendacje_w_zakresie_wdrazania_zalozen_koncepcji_CSR_w_ Polsce.pdf, s.8. (dostęp:7.03.2013).
} 


\section{NAJWAŻNIEJSZE WYZWANIA DLA CSR}

Rynek CSR w Polsce czeka jeszcze wiele wyzwań, do których przede wszystkim należy wzrost zainteresowania koncepcją społecznej odpowiedzialności, nie tylko wśród przedstawicieli biznesu, ale także przez rząd, instytucje państwowe, ośrodki akademickie, organizacje pozarządowe oraz media.

W ogólnopolskim Badaniu świadomości społecznej odpowiedzialności biznesu, przeprowadzonym w 2010 r. na zlecenie Pracodawców Rzeczpospolitej Polskiej, w ramach projektu Koalicja na rzecz odpowiedzialnego biznesu, jedynie 3\% dorosłych Polaków potwierdziło, że zetknęło się z pojęciem społecznej odpowiedzialności biznesu lub angielskim odpowiednikiem tego pojęcia ${ }^{44}$. Wyniki tych badań powinny się stać powodem do refleksji oraz podjęcia systemowych działań na rzecz edukacji i upowszechniania wiedzy na temat CSR wśród różnych zaangażowanych stron. Niedostateczny poziom wiedzy na temat wyzwań zrównoważonego rozwoju oraz koncepcji CSR stanowi jedną z głównych barier na drodze do innowacyjnej i odpowiedzialnej gospodarki ${ }^{45}$.

$\mathrm{Z}$ jednej strony konieczne jest zatem zwiększanie wiedzy i świadomości społecznej dotyczącej odpowiedzialnego biznesu, $\mathrm{z}$ drugiej zaś zachęcanie przedsiębiorstw do stosowania zasad tej koncepcji w praktyce. Dotychczasowe działania promujące ideę społecznej odpowiedzialności biznesu kierowane do firm za pośrednictwem mediów, wydawnictw i konferencji sa mało skuteczne. Tymczasem bez zrozumienia istoty $\mathrm{i}$ możliwości przełożenia idei na codzienną praktykę biznesową hasło to często funkcjonuje jak kolejny zabieg $\mathrm{w}$ ramach polityki public relations. Najlepsze rezultaty przynosi bezpośredni kontakt z przedstawicielami firm i wyjaśnianie, czym jest CSR oraz jakie korzyści biznesowe firma może uzyskać dzięki wdrożeniu tej polityki. Ważne jest także uświadamianie, że odpowiedzialność społeczna nie powinna być postrzegana jako dodatkowy koszt prowadzenia działalności, ale jako siła napędzająca rentowność w ujęciu długoterminowym.

Wyzwaniem dla rządu jest przede wszystkim doskonalenie prawa, dostosowanie go do potrzeb rozwijającej się gospodarki, uwzględniającego europejskie standardy CSR, a także stworzenie zachęt dla polskich przedsiębiorców, sprzyjających wdrażaniu zasad CSR.

Istotnym elementem w upowszechnianiu koncepcji CSR w Polsce powinno być wprowadzanie tej tematyki do programów nauczania na wydziałach ekonomii i zarządzania, a także realizowanie szkoleń w tym zakresie przez organizacje działające na rzecz przedsiębiorczości ${ }^{46}$. Barierą w skutecznym przekazywaniu wiedzy na temat CSR może się okazać brak odpowiednio przygotowanej kadry dydaktycznej, dlatego też uzasadniony wydaje się postulat zawarty w Rekomendacjach $w$ zakresie wdrażania założeń koncepcji CSR w Polsce $e^{47}$ dotyczący wprowadzenia rozwiązań systemowych

\footnotetext{
${ }^{44}$ Badanie świadomości spotecznej odpowiedzialności biznesu,Millward Brown SMG/KRC na zlecenie Pracodawców Rzeczpospolitej Polskiej, w ramach projektu Koalicja na rzecz odpowiedzialnego biznesu, 2010. ${ }^{45}$ http://www.mg.gov.pl/files/upload/13678/Rekomendacje_w_zakresie_wdrazania_zalozen_koncepcji_CSR_ w_Polsce.pdf, s. 14 (dostęp: 7.03.2013).

${ }^{46}$ Więcej informacji: http://www.mg.gov.pl/files/upload/10901/Rekomendacje\%20ws\%20promocji\%20CSR _26\%2010\%202010_ost.pdf (dostęp: 7.03.2013).

${ }^{\overline{47}}$ Więcej informacji: http://www.mg.gov.pl/files/upload/13678/Rekomendacje_w_zakresie_wdrazania_zalozen_ koncepcji_CSR_w_Polsce.pdf (dostęp:7.03.2013).
} 
umożliwiających kształcenie kadr mających kwalifikacje do nauczania o CSR, zarówno na poziomie edukacji elementarnej, jak i wyższej.

Koncepcja społecznej odpowiedzialności powinna znaleźć swoje miejsce zarówno w działalności podmiotów gospodarczych, rządu, organizacji pozarządowych, jak i w systemie edukacji. Warto także podkreślić, że CSR traktowany jako element zarządzania strategicznego przyczynia się do ograniczenia działań o charakterze nieetycznym czy bezprawnym oraz umożliwia uporządkowanie relacji zarówno wewnątrz, jak i na zewnątrz organizacji.

\section{LITERATURA}

[1] Bernatt M., Społeczna odpowiedzialność biznesu. Wymiar konstytucyjny $i$ międzynarodowy ${ }_{2}$ Wydawnictwo Naukowe Wydziału Zarządzania Uniwersytetu Warszawskiego, Warszawa 2009.

[2] Biznes, etyka, odpowiedzialność, red.W. Gasparski, PWN, Warszawa 2012.

[3] Drucker P.F., Społeczeństwo prokapitalistyczne, PWN, Warszawa 1999.

[4] Drucker P.F., Maciariello J.A, Drucker na każdy dzień. 366 refleksji o dobrych praktykach zarzqdzania, Wydawnictwo Eksplanator, Poznań 2011.

[5] Griffin R.W., Podstawy zarzadzania organizacjami, PWN, Warszawa 2004.

[6] PN-ISO 26000, Wytyczne dotyczqce spotecznej odpowiedzialności, Polski Komitet Normalizacyjny, Warszawa 2012.

[7] Rok B., Odpowiedzialny biznes $w$ nieodpowiedzialnym świecie, Akademia Rozwoju Filantropii w Polsce, Forum Odpowiedzialnego Biznesu, Warszawa 2004, http://www.ae.krakow.pl/ gap/doki/23sympozjum/odpbiz.pdf.

[8] Rudnicka A., CSR doskonalenie relacji społecznych $w$ firmie, WoltersKluwer Polska, Warszawa 2012.

[9] Rekomendacje w zakresie wdrażania założeńkoncepcji Społecznej Odpowiedzialności Przedsiębiorstw

Polsce,http://www.mg.gov.pl/files/upload/13678/Rekomendacje_w_zakresie_wdrazania_zaloz en_koncepcji_CSR_w_Polsce.pdf.

[10] Rekomendacje dotyczące upowszechniania idei odpowiedzialnego biznesu w Polsce, Grupa Robocza ds. Promocji CSR Zespołu ds. Społecznej Odpowiedzialności Przedsiębiorstw, http://www.mg.gov.pl/files/upload/10901/Rekomendacje\%20ws\%20promocji\%20CSR_26\%2 010\%202010_ost.pdf.

[11] Warto mieć standardy czyli Kodeks Odpowiedzialnego Biznesu oraz podręcznik do jego wdrażania,http://www.koalicjacr.pl/kodeks.html.

\section{STRONY INTERNETOWE:}

[1] http://www.centrumcsr.pl (dostęp: 7.03.2013)

[2] http://www.csri.org.pl/ (dostęp: 7.03.2013)

[3] http://www.csrinfo.org/pl (dostęp: 7.03.2013)

[4] http://www.globalcompact.org.pl (dostęp: 7.03.2013)

[5] www.iob.org.pl(dostęp: 7.03.2013)

[6] http://www.kozminski.edu.pl/pl/katedry/cebi/cebi (dostęp: 7.03.2013)

[7] http://www.odpowiedzialni.gpw.pl (dostęp: 7.03.2013)

[8] http://odpowiedzialnybiznes.pl (dostęp: 7.03.2013)

[9] http://www.mg.gov.pl (dostęp: 7.03.2013) 


\section{CORPORATE SOCIAL RESPONSIBILITY AS CONCEPT SUPPORTING TO ORDER RELATIONS BETWEEN BUSINESS AND SOCIETY.}

The concept of social responsibility has been changing, evolving and become a subject of public debate. Currently it is regarded not only an idea but also an approach towards management. Gradually it is perceived as a part of corporate management. By means of CSR-based development strategies organisations seek the synergy between economic, social and environmental operating aspects. There are still both supporters and opponents of the CSR idea. The latter ones quote the income as the sole objective of a business enterprise. One shall note that this does not stand in the opposition to the philosophy of social responsibility. CSR does not contradict the idea of profitability although it considers the methods for its achievement. Integrating social responsibility with corporate operations one shall acknowledge the philosophy of social responsibility, its principles and benefits. However, merely $3 \%$ of adult Poles confirmed having come across the term of social responsibility of business or its English equivalent according to a recent national survey on CSR. What is the responsible business? What is the approach of organisations towards the issue of social responsibility? What are the pros and cons of CSR implementation according to its supporters and critics respectively? How does the concept of social responsibility develop in Poland? What action can be taken to raise CSR awareness among interested parties? The main aim of the article is to make the reader familiar with the issue of social responsibility as well as answer all of the above questions.

Keywords: CSR, Corporate Social Responsibility, sustainable and responsible business, social responsibility

DOI: $10.7862 /$ rz.2013.mmr.24

Tekst złożono w redakcji: maj 2013

Przyjęto do druku: listopad 2013 